\title{
Influence of Triassic deposits on water quality of some karstic aquifers to the south of Alicante (Spain)
}

\author{
Influencia de los materiales triásicos en la calidad del agua de algunos \\ acuíferos kársticos del sur de Alicante (España)
}

\author{
J.M. Andreu¹, E. García-Sánchez², A. Pulido-Bosch³ ${ }^{3}$ S. Jorreto ${ }^{3}$, I. Francés ${ }^{3}$
}

\begin{abstract}
Overexploitation of the aquifers of the Middle Vinalopó (SE Spain) has led to problems which, in many cases, are associated with groundwater salinization. The increase in salinity is considered to be due to the dissolution of mineral salts in the Triassic Keuper facies. Geophysical logging of various boreholes in three aquifers in this region confirms the presence of more mineralized waters at depth. The evidence suggests that the phenomenon of salinization results from mixing of these deep waters with more shallow ones. The fall in the ratio of freshwater to saltwater as overexploitation continues and the aquifer is emptied could explain the increased mineralization that has been observed at many boreholes that penetrate these aquifers.
\end{abstract}

Key words: groundwater, geophysical well- logging, overexploitation, salinization, Vinalopó.

\section{RESUMEN}

La fuerte presión sometida a los acuíferos del Medio Vinalopó (SE España) ha originado problemas de sobreexplotación, los cuales van asociados en un gran número de casos a la salinización del agua. El aumento de salinidad ha sido interpretado como debido a la disolución de sales provenientes de los materiales triásicos del Keuper. La testificación geofísica de diversos sondeos de tres acuíferos de esta región ha permitido constatar la presencia de aguas más mineralizadas en profundidad. Por tanto, todo indica que el fenómeno de la salinización se debe a la mezcla del agua más superficial con la profunda. La disminución de la relación agua dulce-agua salada, a medida que progresa la sobreexplotación y el vaciado del acuífero, podría explicar el aumento de la mineralización que han experimentado numerosas captaciones de estos acuíferos.

Palabras clave: aguas subterráneas, testificación geofísica, sobreexplotación, salinización, Vinalopó.

\section{Introduction}

One of the main problems related to intensive groundwater abstractions is the change in water quality. The literature contains relatively frequent examples in which heavy pressure on the groundwater resources are accompanied by a deterioration in the physico-chemical quality of the water (Custo- dio, 1993; Vengosh \& Rosenthal, 1994; Kinniburgh, et al., 1994; Pulido-Bosch et al., 1996; Vrba, 2003). Intensive abstractions from aquifers can mobilize poor quality water and generate mixing processes. This poorer quality water can come from a number of different sources. Amongst the most common are: waters deriving from the same area (Sophocleus, 2002), including drip feed induced from con-

\footnotetext{
1 Dpto. Ciencias de la Tierra y Medio Ambiente. University of Alicante. Apdo. Correos, 99, 03080 Alicante. Email: Andreu.Rodes@ua.es

2 Dpto. de Agroquímica y Medio Ambiente. University Miguel Hernández. Avda. Ferrocarril, s/n, E-03202 Elche (Alicante). Email: ernesto.garcia@umh.es

3 Dpto. de Hidrogeología y Química Analítica. University of Almería. Edif. Central, E-04120 La Cañada (Almería).

Email: sjorreto@ual.es; isaacf@ual.es; apulido@ual.es
} 
fined layers or even from congenital water held in the rock matrix (Elliot et al., 1999), from the dissolution of saline formations (Inoubli, 2005; Magri et al., 2009), from water transferred from adjacent aquifers containing polluted or highly-mineralized water (Marie \& Vengosh, 2001), from the mobilization of deep flows (Gunn et al., 2006); in the case of coastal aquifers, changes in groundwater quality can arise due to seawater intrusion associated with the advance of the saline wedge or upconing processes (Zektser et al., 2005).

In the majority of cases, deterioration of water quality usually progresses to the point where the water is unusable for its destined purpose. Once the deterioration reaches this stage, the aquifer abstractions are typically abandoned, one by one. This new situation means exploitation of the groundwater resources diminishes until the aquifer is no longer over-exploited, a situation that is defined as the exhaustion of the water resources by Harou \& Lund (2008) in considering how to overcome overexploitation. In the area of Vinalopó, in south-eastern Spain, intensively-exploited aquifers can be found exhibiting varying degrees of water quality deterioration.

The area of Vinalopó, and specifically the Middle Vinalopó, is one of the areas in Spain most severely affected by overexploitation (Custodio, 2002). The main reasons for this overexploitation are the limited extent of the aquifers (the majority of which cover less than $50 \mathrm{~km}^{2}$ surface area), and the location in a semiarid Mediterranean climatic region. These features mean that these water resources are strictly limited. During the second half of the XX century a transformation occurred in this region from traditional crops to intensive agriculture, and this quickly led to overexploitation of the aquifers, accompanied by generalized salinization.

The main objective of this study was to advance the understanding of the salinization processes that these groundwaters have suffered over recent decades. To achieve this, a compilation of historical hydrogeochemical data was made covering the Middle Vinalopó aquifers, which was then compared to the present-day situation. The aquifers selected for the study correspond to those where greatest knowledge was available. The study was completed by undertaking borehole logs for electrical conductivity and temperature. This paper presents the initial conclusions drawn from reviewing all the information.

\section{Regional hydrogeological context}

The Middle Vinalopó belongs to the External Zones of the Betic Cordillera, and more precisely to the sector in Alicante province where the Subbetic contacts the Prebetic. Set in this geological context is a series of predominantly carbonate reliefs dating from the Jurassic to the Tertiary that behave as aquifers. The most recent hydrogeological audit identified more than twenty aquifers in this district. The area is dissected by the river Vinalopó, whose valley marks an axis of discontinuity of the geological strata between one side and the other. All along this river basin are outcrops of Triassic clayey-evaporitic Keuper facies. This has led to the interpretation that the course of the Vinalopó is a tectonic accident that affects the basement, causing a diapiric extrusion from the Triassic strata. (Leret et al., 1976). But in addition, the Triassic terrains are highly significant in this region since they form the substratum of the secondary sedimentary cover that forms the present relief. Therefore, whether because acts as the base that underlies other materials, or because of its diapiric nature, its presence determines the structural disposition of the aquifer deposits and takes on great significance from a hydrogeological point of view.

Normally, the Triassic outcrops form clayey masses accompanied by accumulations of gypsum, which can occasionally contain include carbonate rocks, mostly dolomites. In this area it is not possible to observe the complete type sequence defined by Ortí (1974) for the Triassic in the Levante region of Spain, in which there are two evaporite series intercalated by an intermediate detritic series. Nevertheless, the presence of saline materials corresponding to the upper evaporite series has been confirmed by mining operations in the Pinoso diapir, as well as in other diapirs such as Villena (in the Vinalopó basin), and in the diapirs of Jumilla and La Rosa in the province of Murcia (Mancheño \& Rodríguez-Estrella, 1985).

In general, it is considered that the Triassic Keuper deposits are impermeable, so that they act as hydraulic barriers that confine many of the different aquifer systems. It can be considered as the impermeable material par excellence for this region. Nevertheless, as shown in the Middle Vinalopó, the presence of springs and resurgences in these deposits largely invalidates such a generalization. The hypersaline nature of these springs confirms the presence of salts at depth, even though these do not manifest at the ground surface. 


\section{Studied aquifers}

Of the various aquifers of the Middle Vinalopó two were selected west of the river (Crevillente and Horna) and one to the East (Cid aquifer). Their principal features are described below:

The Crevillente aquifer comprises a sequence of more than $500 \mathrm{~m}$ Jurassic limestones, dolomitic limestones and dolomites belonging to the Subbetic. It extends over $140 \mathrm{~km}^{2}$ between the Crevillente and Reclot sierras. The aquifer is partly delimited by Triassic terrains. There are also point outcrops of these rocks in the interior of the aquifer and they appear at depth in some boreholes. As a result, the Triassic has been interpreted several times as the impermeable base of the aquifer. This aquifer has been intensively exploited for nearly 50 years, leading to a generalized, though unequal, drop in water level throughout the aquifer. The part of the aquifer that has suffered greatest emptying is its south-eastern sector, where the fall in water level is more than $300 \mathrm{~m}$, and where the most serious problems related to water quality deterioration manifested. Other parts of the aquifer, where the fall in water level was not so sharp, do not appear to have suffered a similar deterioration in water quality.

Horna aquifer is formed by a small, elongate relief orientated NW-SE and only $3 \mathrm{~km}^{2}$ in extent. It is situated between the Crevillente aquifer and the river Vinalopó and comprises more than $200 \mathrm{~m}$ depth of limestones, marly limestones and bioclastic limestones that date from the Eocene to the Oligocene. Although its boundaries do not outcrop on the ground surface, everything indicates that laterally it is mostly confined Lower Cretaceous and Miocene marly strata, though on the southern border, there seems to be hydraulic connection with recent detritic deposits. Further to the East, the Triassic rocks of the Vinalopó valley outcrop. The impermeable base is formed by marls belonging to the Tertiary series, although, one cannot rule out the presence of Keuper clays and gypsums. This aquifer was first exploited in the seventies, which was when the first salinity problems became apparent: some of the deepest boreholes never actually became operational due to the high salinity of the waters pumped from them.

Cid aquifer, on the eastern bank of the Vinalopó, extends over a little more than $30 \mathrm{~km}^{2}$. It belongs to the Prebetic domain and comprises mainly gravelly limestones, micritic limestones and marly limestones with intercalations of marls, which date from the Albian to the Upper Cretaceous. The thickness of this series exceeds $400 \mathrm{~m}$. Its impermeable base consists of more than $300 \mathrm{~m}$ Lower Cretaceous subnodular marls and marly limestones. Keuper faicies also outcrop in the vicinity. Exploitation of this aquifer began at the end of the seventies. Since the abstractions were much greater than the system's resources, the water table fell by up to $250 \mathrm{~m}$.

\section{Water Quality Changes}

One of the difficulties in establishing how groundwater quality has changed as exploitation of the aquifer progresses is the lack of data on the initial, pre-abstraction characteristics of the groundwater. With the exception of certain cases in particular, the earliest chemical analyses date back to when the aquifers were already overexploited.

A Piper diagram of the water from some of the boreholes where the degree of mineralization has changed establishes that, initially, the water facies were of mixed and chloride type, despite the fact that the aquifer is formed from carbonate rocks (Fig. 1b). However, over time there was an clear evolution towards sodium chloride facies and, therefore, towards characteristics that resemble more closely the saline springs found in the Triassic Vinalopó terrains.

In order to understand the importance of the chloride facies on the total saline content (TDS) Figure 2 shows the ratios between these parameters, based on samples taken during the summer of 2007 in the Crevillente and Horna aquifers, as well as some earlier samples from the Cid aquifer. There is a close linear fit, with an $r^{2}$ of 0.967 , which confirms that chloride is the principal ion responsible for the increase in the degree of mineralization. However, when TDS is plotted against the sum of $\mathrm{Cl}+\mathrm{SO}_{4}$ there is an even better fit, with an $\mathrm{r}^{2}$ de 0.9879 , which shows how the salinity of the water arises from both these ions. These findings indicate a predominance of the dissolution processes acting on the evaporitic salts (gypsums and halite) associated with the Keuper facies.

\section{Vertical mineralization of the water}

To establish the nature of the mineralization across the saturated zone, a number of surveys were done between September and November 2007 to record water conductivity and temperature of the 

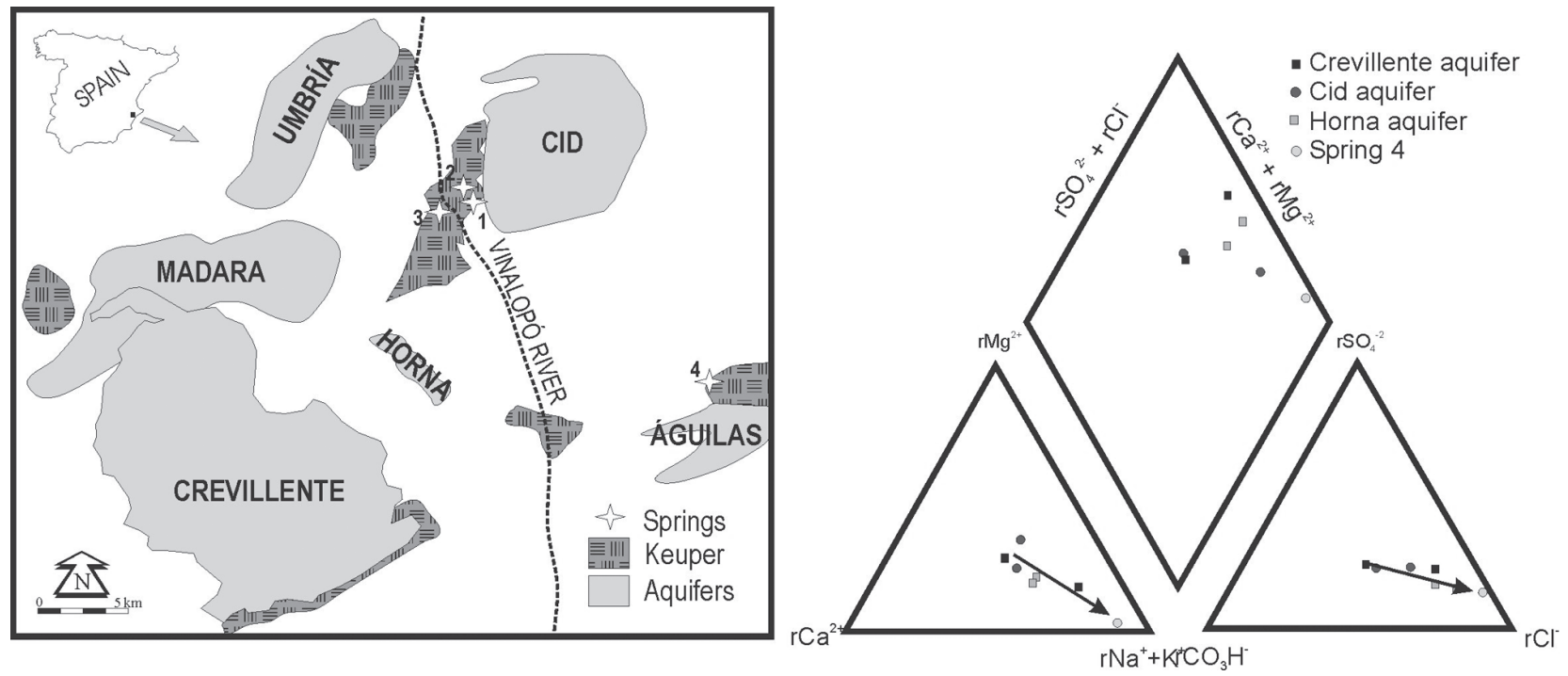

Fig. 1.-A) Location of the selected aquifers in the Middle Vinalopó, the Keuper outcrops and the location of hypersaline springs. B) Piper Diagram showing water samples belonging to the study aquifers where increases in salinity have occurred.
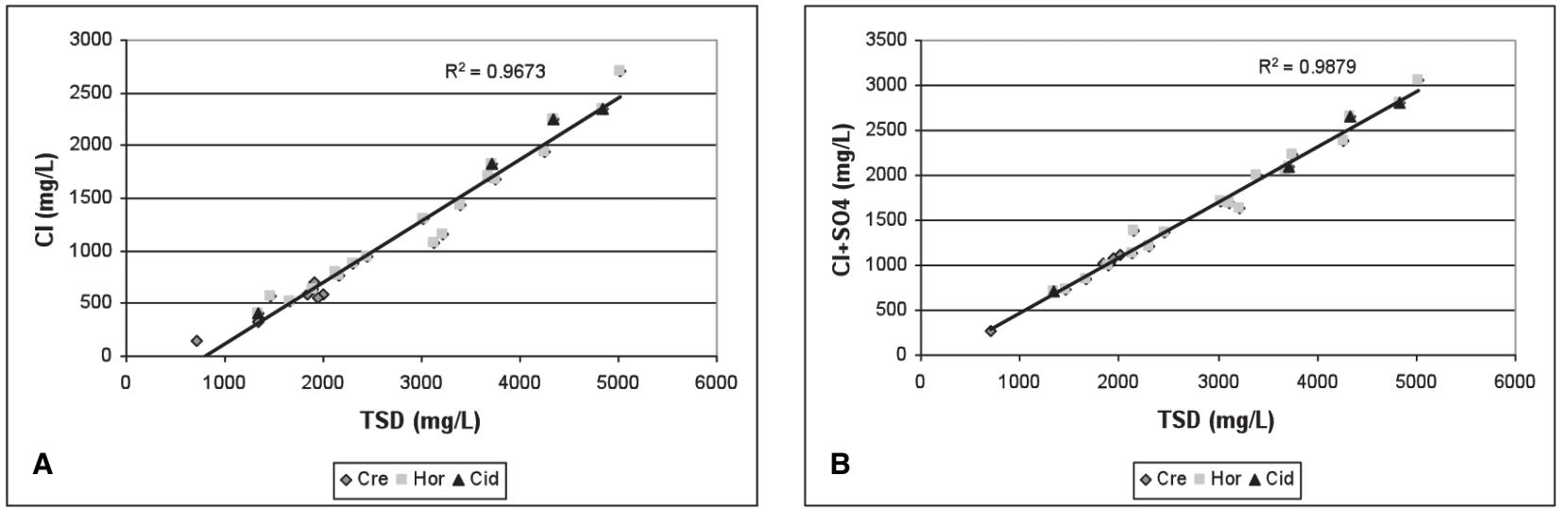

Fig. 2.-Chloride versus TSD (A). Chloride plus sulphate versus TSD (B).

water in the Crevillente and Horna aquifers. In addition, earlier diagraphs for these aquifers were recovered, as well as for the Cid aquifer (Pulido et al., 1998; Andreu et al., 2008). These logs were done using a Geovista geophysics logger provided by the "Water Resources and Environmental Geology" research group at the University of Almería. The equipment is mounted on a four-wheel drive vehicle, and consists of a series of probes (short, long and normal resistivity, electrical conductivity, temperature, flowmeter, etc.), a winch with a $1,500 \mathrm{~m}$ long high-resistance cable, and a system for data storage and processing. The main results are described below.
For the Cid aquifer, the longest diagraph $(120 \mathrm{~m})$ was selected, since this provides more complete data on the saturated zone (Fig. 3, left). In broad terms, there is a surface band approximately $40 \mathrm{~m}$ thick where conductivity is between 1,500 and $2,600 \mu \mathrm{S} / \mathrm{cm}$. Below this is a wide band, which gradually increases in conductivity, with a gradient of $80 \mu \mathrm{S} / \mathrm{cm}$ per metre descent. At the bottom of the borehole is more highly-mineralized water, whose conductivity is $7,400 \mu \mathrm{S} / \mathrm{cm}$. In contrast, temperature remains a practically-constant $25.1{ }^{\circ} \mathrm{C}$ throughout the bore log.

Of the existing diagraphs for the Crevillente aquifer, those surveyed in its south-eastern sector 


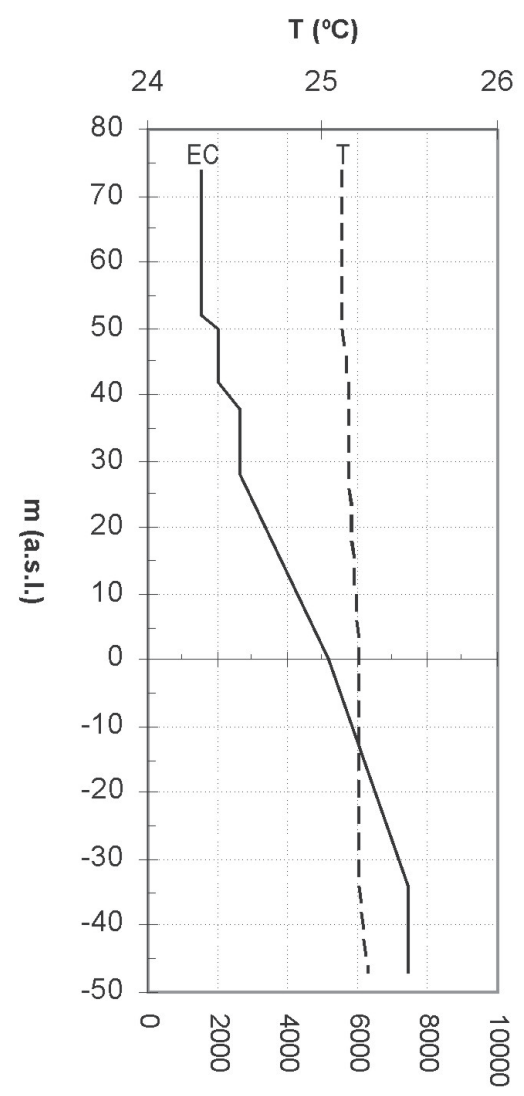

$\mathrm{EC}(\mathrm{micros} / \mathrm{cm})$

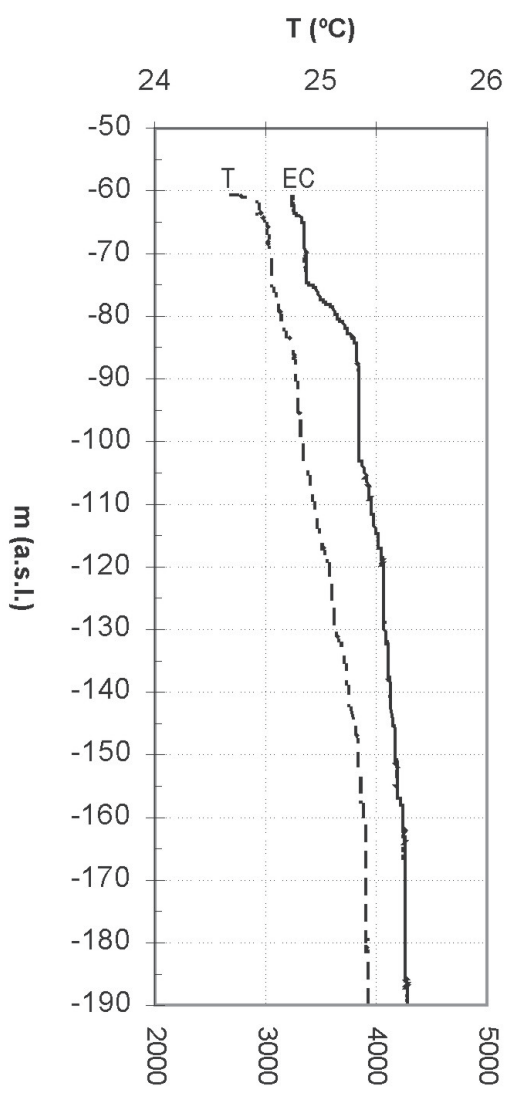

$\mathrm{EC}(\mathrm{micros} / \mathrm{cm})$

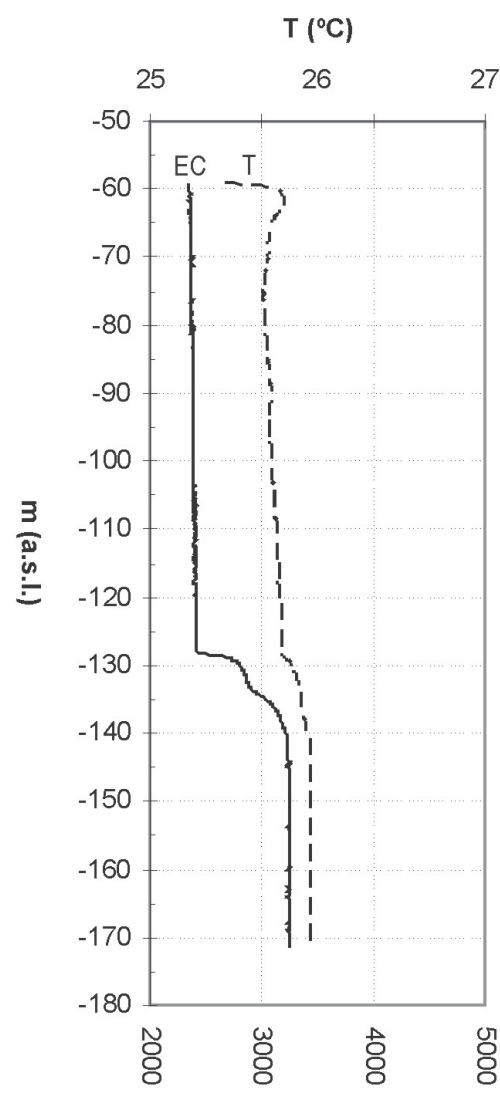

$\mathrm{EC}(\mathrm{micros} / \mathrm{cm})$

Fig. 3.-Diagraphs of boreholes in the Cid (left) and Crevillente (T-10 centre and T-6 right) aquifers.

were selected, since they were the only ones that show variation in the degree of mineralization of the water at depth. These logs also coincided with the part of the aquifer that was most severely affected by the deterioration in water quality, and where many boreholes were abandoned as a result. Borehole logs over the rest of the aquifer show stable water quality throughout the water column. Electrical conductivity in the latter cases ranged between 950 and $2,150 \mu \mathrm{S} / \mathrm{cm}$ depending on the aquifer point, values that coincide with the EC of the water abstracted from the boreholes.

The water columns logged in the south-eastern sector exceed $100 \mathrm{~m}$ in both cases (Fig. 3). In general, there is a slight increase in EC with depth. In borehole T-6 (Fig. 3, right), one can differentiate the first $70 \mathrm{~m}$, in which the water has an EC of between 2,354 and $2,710 \mu \mathrm{S} / \mathrm{cm}$. Below this is an approximately $10 \mathrm{~m}$ band where the sharpest rise in EC occurs, with a mean gradient of close to $50 \mu \mathrm{S} / \mathrm{cm} / \mathrm{m}$. Lastly, the water beneath has EC of more than $3,200 \mu \mathrm{S} / \mathrm{cm}$. Temperature shows virtually no variation. In turn, borehole T-10 (Fig. 3 centre) shows alternating layers in which EC is constant in some bands and increases in other. The least-mineralized water lies in the first $14 \mathrm{~m}$ where mean EC is $3,300 \mu \mathrm{S} / \mathrm{cm}$, whilst the deepest part of the log records values close to $4,200 \mu \mathrm{S} / \mathrm{cm}$. Temperature, discounting the influence of the ground surface, shows a slight increasing trend.

Three diagraphs are given for the Horna aquifer (Fig. 4), logged over 45 to $102 \mathrm{~m}$. All show an upper band, 20 to $40 \mathrm{~m}$ thick, that corresponds to less-mineralized water. Conductivity of this water is not the same in all the boreholes, but varies between 1,600 and $4,400 \mu \mathrm{S} / \mathrm{cm}$. Whatever its value, EC is quite stable within this zone. Beneath, there is a considerable and quite rapid increase in EC. Sometimes, this rise in EC occurs in several jumps. Peak values are between 12,000 and $32,000 \mu \mathrm{S} / \mathrm{cm}$ depending on the aquifer point. This mineralized zone is also charac- 

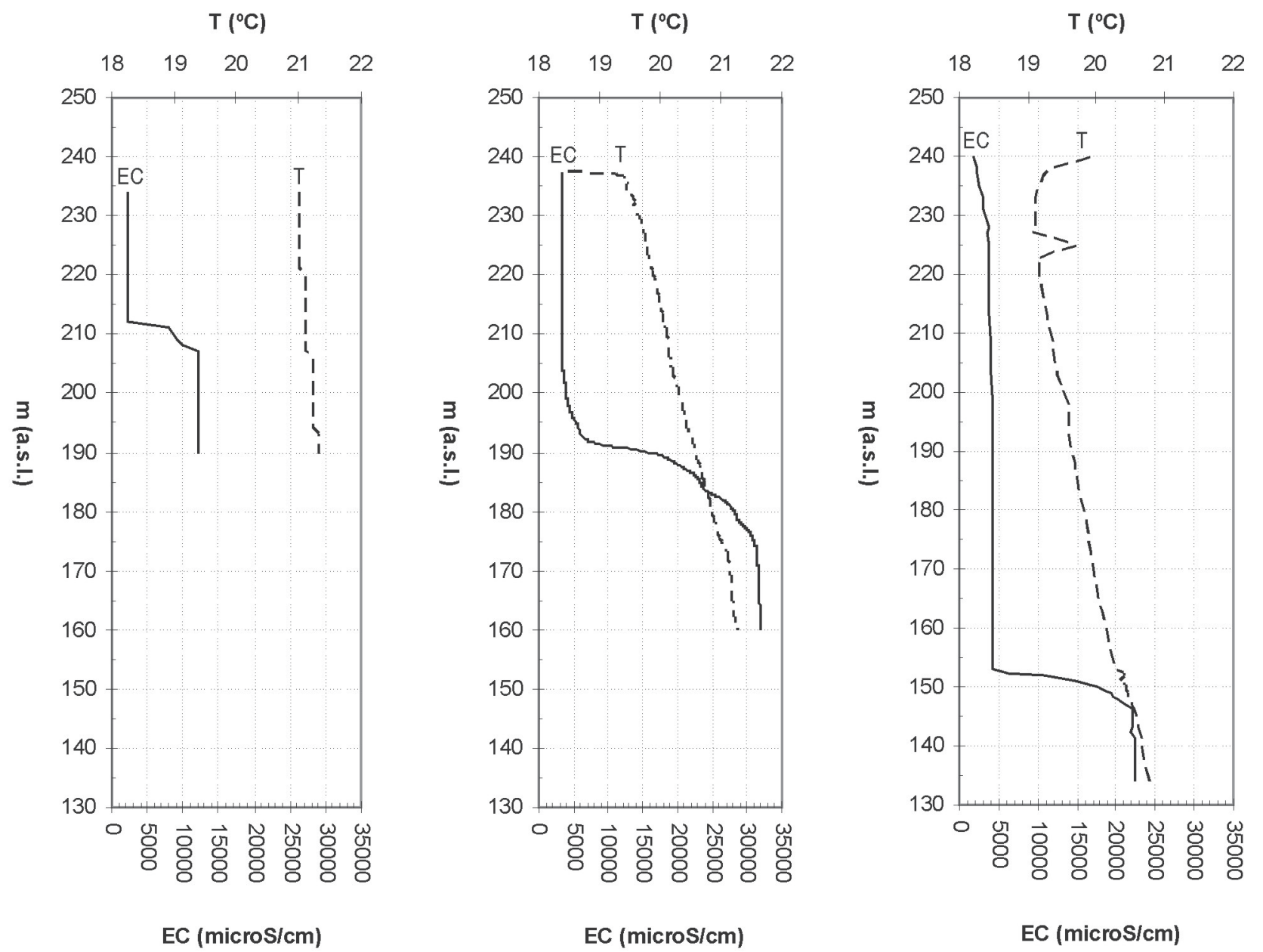

Fig. 4.-Diagraphs of boreholes $\mathrm{H}-1$ (left), $\mathrm{H}-2$ (centre) and $\mathrm{H}-3$ (right) from the Horna aquifer.

terized by a marked stability in EC down as far as the base of the logging column. In terms of water temperature, the longest borehole log showed an increase from 19 to $21^{\circ} \mathrm{C}$, while the shallower borehole (H-1) showed virtually no variation of this parameter.

\section{Discussion}

A comparison of the earliest analyses available for these groundwaters with the current ones clearly establishes that as the exploitation progresses, so the mineralization increases and the quality decreases. This evolution seems to be quite common throughout the Middle Vinalopó (Andreu et al., 1998; Lambán \& Aragón, 2004; Andreu et al., 2008). However, not all the aquifers showed an identical deterioration, nor was the increase in salinity uniform within any particular aquifer. Of the three aquifers selected, the most-severely affected is the Cid, where there was a practically complete abandonment following the deterioration in its groundwater quality. The Crevillente aquifer showed a fall in quality in certain sectors, whilst in the Horna, the abstraction of saline water during the intensive exploitation phase led to early abandonment of the aquifer.

The increase in the degree of mineralization is related, above all, to increases in the chloride ion and, to a lesser extent, the sulphate ion. This has led to the facies becoming more chloride type over time. In the absence of an isotopic assay to establish with greater certainty the origin of the salinity, all the available data indicates that it must come from the Triassic Keuper deposits. The Triassic terrains 
are the only strata common to the three systems and, despite the fact that they are all carbonate aquifers, their lithologies belong to different depositional environments and different ages. Thus, the only common link appears to be the Triassic Keuper deposits.

The dissolution of halite appears to provide the main source of sodium and chloride in the groundwater of these aquifers, with water samples giving ion ratios of close to unity in the majority of cases, similar to the case encountered in the saline spring 4 (Fig. 1) and in other water related to the dissolution of evaporite deposits in other geological contexts (Grobe et al., 2002; Inoubli, 2005). Only in the Horna aquifer is the ionic ratio slightly lower (0.7-1), and this could be explained by the intervention of other water-rock interactions (this aquifer contain marl-rich sequences) that upset the ion ratio.

Other aspect worth highlighting is that not all of the points show the same degree of deterioration, not even within the sectors affected by the salinization. The diagraphs for some abstraction points show that the most-mineralized water is at the base of the boreholes, which suggests differentiation by gravity of water within the aquifer. This kind of hydrochemical disposition has been highlighted in many aquifer formations whose saline wedges are the result of dissolution of evaporite deposits and mixing with brines (Tellman, 1986; Hanor \& Mcintosh, 2007). Of the three aquifers logged, the greatest variation in mineralization between the surface and bottom water was in the Horna aquifer, where differences in EC of nearly $30,000 \mu \mathrm{S} / \mathrm{cm}$ were recorded.

The hydrochemical disposition could explain why the deepest boreholes would pump a water mixture with a higher proportion of basal water and therefore more saline water, whilst shallower boreholes nearby would basically pump water the more dilute surface water. Such a situation appears in the Horna aquifer, where the shallowest boreholes deliver less mineralized water. In addition, this hydrochemical zoning implies that, as the aquifer becomes desaturated as a consequence of overabstraction, the ratio of mixing between the fresh and the saline moves in favour of the saline water so that, over time, an increase is noted in the degree of mineralization of the water extracted.

Hydrogeochemical zoning seems to be evident to a greater or lesser extent in each of the three aquifers, and could explain part of the change in water quality that occurs as overexploitation of the aquifer progresses. However, there does not seem to be a direct correlation between depth and the increase in mineralization. In spite of the fact that only a small number of boreholes were logged and the information obtained may still be biased as a result, it is possible to confirm that each borehole has a distinct mineralization profile. Even when points from the same aquifer are compared, the jumps in mineralization occur at different levels, in spite of the geographical proximity of the points. This invalidates the idea of a static hydrochemical differentiation, although it is conceivable that the karstic character of these aquifers, whereby flows in the saturated zone are determined by the greater or lesser transmissivity of the rock in different parts, could be the explanation for why a static differentiation would be modified or disturbed.

\section{ACKNOWLEDGEMENTS}

This study was financed from the research projects CGL2004-03627/HID from the CYCIT and GV07/143 from the Generalitat Valenciana; it was undertaken in the framework of the UNESCO project IGCP-513. We are grateful to the personnel of SAT 3412 from Aspe for allowing and assisting the borehole loggings in their installations.

\section{References}

Andreu, J.M.; Estévez, A.; Morell, I. \& Pulido-Bosch, A. (1998). La contaminación de acuíferos kársticos ligada a la sobreexplotación. In: La contaminación de las aguas subterráneas: un problema pendiente (Samper, J.; Sahuquillo, A.; Capilla, J.E. \& Gómez, J.J., eds.), ITGE, Madrid, 335-361.

Andreu. J.M.; García-Sánchez, E.; Jorreto, S.; Francés \& Pulido-Bosch, A. (2008). Evaluación de la calidad del agua subterránea en la actual zona saturada del acuífero de Crevillente (Alicante). Geogaceta, 44: 151154.

Custodio. E. (1993). Hydrogeological and hydrochemical aspects of aquifer overexploitation. In: Aquifer overexploitation. Selected papers on Aquifer overexploitation from the 23rd International Congress of the International Association of Hydrogeologists, Verlag Heinz Heise, Hanover, 3: 3-27.

Custodio, E. (2002). Aquifer overexploitation: what does it mean? Hydrogeology Journal, 10: 254-277. doi: 10.1007/s 10040-002-0188-6

Elliot T.; Andrew, J.N. \& Edmunds W.E. (1999). Hydrochemical trends, paleorecharge and groundwater ages in the fissured Chalk aquifer of the London and Berkshire basins, UK. Applied Geochemistry, 14: 333-363. doi:10.1016/S08832927(98)00060-2 
Grobe M. \& Machel, H.G. (2002). Saline groundwater in the Münsterland Cretaceous Basin, Germany: clues to its origin and evolution. Marine and Petroleum Geology, 19: 307-302. doi:10.1016/S0264-8172(02)00019-3

Gunn, J.; Bottrell, S.H.; Lowe, D.J. \& Worthington, S.R.H. (2006). Deep groundwater flow and geochemical processes in limestone aquifers: evidence from thermal water in Derbyshire, England. UK. Hydrogeoogy Journal, 14:868-881. doi:10.1007/s10040-006-0022-7

Hanor, J.S. \& McInstosh, J.C. (2007). Diverse origins and timing of formation of basinal brines in the Gulf of Mexico sedimentary basin. Geofluids, 7: 227-237. doi:10.1111/j.14688123.2007.00177.x

Harou, J.J. \& Lund (2008). Ending groundwater overdraft in hydrologic-economic systems. Hydrogeoogy Journal, 16: 1039-1055. doi:10.1007/s10040-008-0300-7

Inoubli, N.; Bouri, S. Gouasmia, M. \& Ben Dhia H. (2005). Geothermal waters in relation with Triassic Evaporitic Structures (Norh-Western, Tunisia). Proceedings of the World Geothermal Congress, Antalya, Turkey: 1-5.

Kinniburgh, D.G.; Gale, I.N.; Smedley, P.L.; Darling, W.G.; West, J.M.; Kimbling, R.T.; Parker, A.; Rae, J.E.; Aldous, P.J. \& O'Shea, M.J. (1994). The effects of abstraction of groundwater fom the London Basin aquifers on groundwater quality. Applied Geochemistry, 9: 175-195.

Lambán, L.J. \& Aragón, R. (2004). Influence of intensive exploitation on groundwater salinity: the Quibas hydrogeological unit (Murcia, SE Spain). In: Groundwater and saline intrusion. Selected papers from the 18th Salt Water Intrusion Meeting, Cartagena, Spain (Araguás, L.; Custodio, E. \& Manzano, M., eds.). Publicaciones del IGME, Serie Hidrogeología y aguas subterráneas, 15: 551-563.

Leret, G.; Núñez, A.; Colodrón, I. \& Martínez del Olmo, W. (1976). Mapa y memoria explicativa de la hoja 981 (Elda) del Mapa Geológico Nacional a escala 1:50.000. Plan MAGNA, IGME, Madrid.

Magri, F.; Bayer U.; Rekdeger, A.; Otto, R. Thomsen, C. \& Maiwald, U. (2009). Salty groundwater flow in the shallow and deep aquifer systems of the SchleswigHolstein area (North German Basin). Tectonophysics, 470: 183-194. doi:10.1016/j.tecto.2008.04.019
Mancheño, M.A. \& Rodríguez-Estrella, T. (1985). Geología de los diapiros triásicos en el noreste de la provincia de Murcia. Estudios Geológicos, 41: 189200. doi:10.3989/egeol.85413-4701

Marie A \& Vengosh A. (2001). Sources of salinity in groundwater from Jericó area Jordan Valley. Ground Water, 39: 240-248. doi:10.1111/j.17456584.2001.tb02305.x

Ortí, F. (1974). El Keuper del Levante español. Estudios Geológicos, 30: 7-46.

Pulido-Bosch, A.; Morell, I. \& Andreu, J.M. (1996). Modifications hydrogéochimiques provoquées para la surexploitation d'un aquifère karstique, Comptes Rendus de la Academie de Science de Paris, 323, ser II: 313-318.

Pulido-Bosch, A.; Andreu, J.M.; Estévez, A. \& Ayanz, J. (1998). Zonation hydrogéochimique verticale dans l'aquifère karstique du Cid (Alicante, Espagne). Comptes Rendus de la Academie de Science de Paris, 326, ser II: 421-426.

Sophocleous, M. (2002). Interactions between groundwater and surface water: the state of the science. Hydrogeology Journal, 10: 52-67. doi: 10.1007/s10040-001-0170-8

Tellman, J.H.; Lloyd, J.W. \& Walters, M. (1986). The morphology of a saline groundwater body: its investigation, description and possible explanation. Journal of Hydrology, 83:1-21.

Vengosh, A. \& Rosenthal, E. (1994). Saline groundwater in Israel: its bearing on the water crisis in the country. Journal of Hydrology, 156: 389-430. doi:10.1016/00221694(94)900876

Vrba, J. (2003). The impact of aquifer intensive use on groundwater quality. In: Intensive use of groundwater: challenges and opportunities (Llamas, R. \& Custodio, E., eds.) Balkema, Madrid: 113-132.

Zektser, S.; Loáiciga, H.A. \& Wolf, J.T. (2005). Environmental impacts of groundwater overdraft: selected case studies in the southwestern United States. Hydrogeology Journal, 47: 396-404.

Recibido el 3 de diciembre de 2009 Aceptado el 24 de febrero de 2010 Publicado online el 22 de abril de 2010 